\title{
4.9 Robbery
}

Louise E. Porter

\section{Definition}

In England and Wales, section 8 (1) of the Theft Act 1968 states that 'a person is guilty of robbery if he[/she] steals, and immediately before or at the time of doing so, and in order to do so, helishe] uses force on any person or puts or seeks to put any person in fear of being then and there subjected to force? Robbery can, therefore, inwolve a range of threatening, forceful andior violent behaviour, including verbal threats, physical force or weapons (armed robbery). Further, robbery can vary from stealing from organizations (banks, post offices, shops, security vehicles) to personal property, where the latter is often termed 'mugging', 'snatch theft' or 'street robbery' (so termed because of its most frequent location). Victims of robbery can range from owners of commercial estabilishments or their employees (commercial robbery), to individuals going about their daily routine or even in their own homes (personal robbery).

According to Smith (2003), $45 \%$ of UK personal robberies involve victims under 21 years old, with male victims of personal robberies more likely than females. In contrast, Matthews (2002) notes that commercial armed robbers most frequentily target lone female employees.

\section{Behavioural/psychological models}

Many studies that explore robbery do so in terms of variations in the frequencies of offence characteristics (for example, Barker of al. 1993, Marsden 1989; Smith 2003). Further, some explore the combinations of these charioteristics and propose models to explain the paychological meaning of such patterns of variation. For example, Alison et al. (2000) explored themes of robbery offence characteristics, in terms of their statistical co-occurrences,

Brown, Jennifer M. (Editor); Campbell, Elizabeth A. (Editor). Cambridge Handbook of Forensic Psychology.

Cambridge, , GBR: Cambridge University Press, 2010. p 561.

http://site.ebrary.com/lib/griffith/Doc?id=10392876\&ppg=561

Copyright (C) 2010. Cambridge University Press. All rights reserved

May not be reproduced in any form without permission from the publisher, except fair uses permitted under U.S. or applicable copyright law. 
taken from interviews with armed robbers, while Porter and Alison (2006a) explored themes in group robbery offences. Both studies used Smallest Space Analysis, a multidimensional scaling technique, to explore and confirm these patterns (see chapters 8.2 and 8.3 for an explanation of these techniques).

Alison at al. (2000) reported three themes of robberies, termed 'Cowboys", 'Bandits' and 'Robin's men' based upon the defining features of each set of behaviours. While 'Robin's men' tended to show more evidence of planuing and organization, such as controlling potential witnesses by forcing them to the floor and tying them up, 'Bandits' are described as aggressive, terrorizing victims, and using demeaning language and gatuitous violence. 'Cowboys' are described as reckless, needlessly attacking victims with violence and verbal threats, and using tirearms. 'Cowboys' are also reported to be associated with more victim resistance. These themes were purticularly differentiated in terms of professionalism, where 'Robin's men' were considered most 'professional', exhibiting evidence of pre-planning and control over victims, while 'Cowboys" were least professional. 'Robin's men' most dearly embody the traditional picture of robbery offenders as organized groups who target secure establishments for large amounts of money.

In contrast, Porter and Alison (2006a) specifically examined group robbery offences from the perspective of an interpersonal circumplex model (Leary 1957), seeking evidence for two dimensions of Dominance vs Submission and Cooperation vis Hostility. They found offence behaviours to co-occur in a pattern consistent with the four themes that these two dimensions represent. Offence behaviours indicative of the Dominance theme demonstrated controlling behaviours that totally disabled victims, such as binding and gagging, and similar to the methods of Alison at al's (2000) 'Robin's men'. In opposition to the Dominance theme (both in meaning and geographically in the spatial statistical output), the Submission theme showed few offender variables but a greater proportion of victim 'control', where victims refused to do as they were told, struggled and/or ran awiy, indicating, in contrast to the previous theme, a lack of offender control or presence of offender Submission to the rictin. The theme of Cooperation incorporated behaviours designed to coerce victims into participating in the robbery, for example using verbal threats, often backed up by weapons, and demanding victims hand over goods or instructing them to open tills/safes. In opposition to this (again, both semantically and geographically) behaviour indicating Hostility showed offenders using violent means, manually restraining or searching victims and harming, sonetimes killing, victims with weapons improvised from the scene of the robbery.

Brown, Jennifer M. (Editor); Campbell, Elizabeth A. (Editor). Cambridge Handbook of Forensic Psychology.

Cambridge, , GBR: Cambridge University Press, 2010. p 562.

http://site.ebrary.com/lib/griffith/Doc?id=10392876\&ppg=562

Copyright $@ 2010$. Cambridge University Press. All rights reserved.

May not be reproduced in any form without permission from the publisher, except fair uses permitted under U.S. or applicable copyright law. 
Further, Porter ind Alison (2006a) demonstrated thematic differences between commercial and personal robberies. While commercial robberies tended to involve more co-operative behaviours than persomal robberies, personal robberies tended to show more hostile features. Potential explaniations for these differences may lie in the nature of the offences. For example, offenders may need to seek victims' cooperation for successful commertial robbery, given that they are likely to want access to cash registers and safes and may not have access themselves. There may also be a potentially higher number of people to control in commercial establishments (both employees and customers) than in a street robbery, and decreised physical contact (employees behind counters or screens), necessitating a more controlled approach than physical force and violence. Finally, victin cooperation maty be more likely when they are not being robbed of their own personal property, meaning offenders' demands for cooperation may be more likely to be met in commerciall robbery, while personal robbers may need (or expect to need) more force in order to successfully part wictims and their valuables. However, Porter and Alison (2006i) also suggest that these differences in interpersonal style towards the victim could reflect differences in motivation.

\section{Motives and processes}

Ethnographic work in recent years has seen researchers conduct interviews with both active robbers "on the street' in the US Uacobs and Wright 1999: Wright and Decker 1997) and with convicted robbers in the UK (Wright, Brookman and Bennett 2006) to explore motivations for committing robbery. These anthors concluded that while the main motiwation for robbery is a need for fast cash, the 'decision' to rob is influenced by 'street culture'.

While street culture may involve transience and unemployment, leading to financial needs for subsistence, these needs are not always basic for robbery offenders, but are often for luxury items. Indeed, Jacobs and Wright (1900) argue that street culture embodies values such as a 'party' lifestyle inrolving extitement and hedonism, with minimal responsibilities or forward thinking. Further, such a lifestyle also inwolves social instability and a need for status, with pressure to display certain stitus symbols to indicate wealth (for example, a car, clothes, jewellery). For these individuals, legitimate work, if available, would likely be too restrictive on their lifestyle, would not pay enough to cover the lifestyle sought or offer delyyed gratification (i.e, time between effort and pay). In contrast, Jacobs and Wright (1099) argue, robbery is seen as easy fast cash,

Brown, Jennifer M. (Editor); Campbell, Elizabeth A. (Editor). Cambridge Handbook of Forensic Psychology.

Cambridge, , GBR: Cambridge University Press, 2010. p 563.

http://site.ebrary.com/lib/griffith/Doc?id=10392876\&ppg=563

Copyright $\odot$ 2010. Cambridge University Press. All rights reserved.

May not be reproduced in any form without permission from the publisher, except fair uses permitted under U.S. or applicable copyright law. 


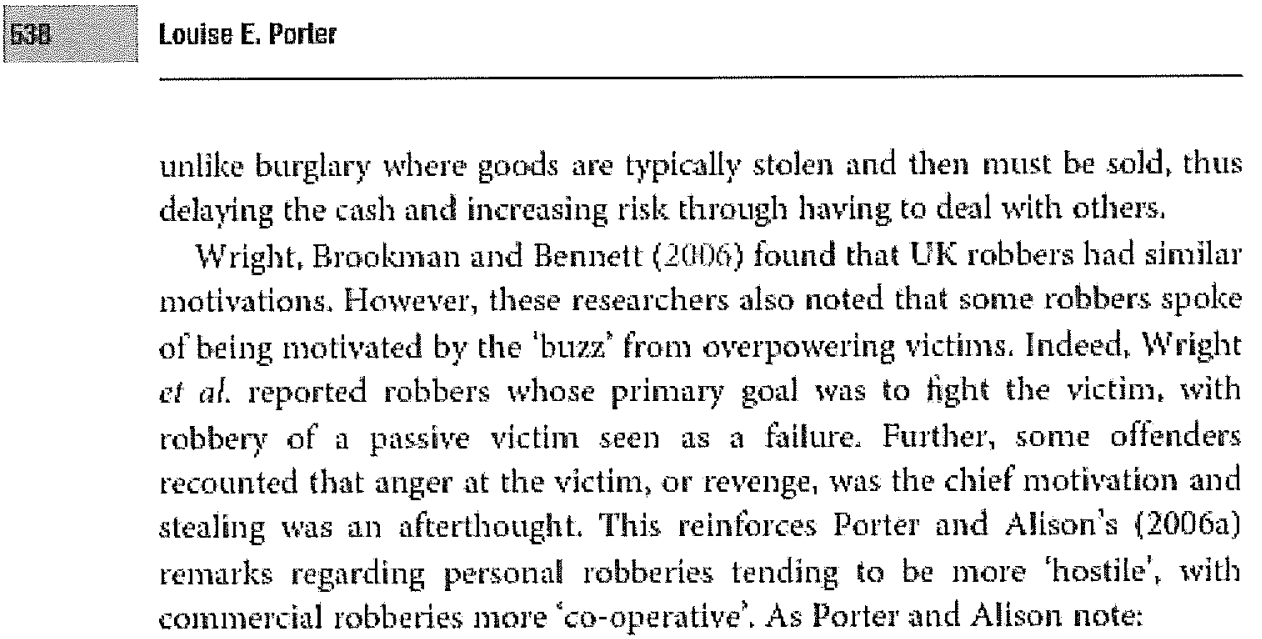

It is possible that personal and commerdial robbers cone from a difterent offending culture that predisposes then to behave with a particular interpersonal slyle. Thus, [for personal robbers] the crime in itself is a means to status, rather than just the gaining of property/money to gain status, and violence is a necessary part of the process. (Porter and Alison 20060, pp. 340-1)

There seem, therefore, to be two perspectives regarding motivations for robbery. First, many researthers offer a rational choice perspective, describing robbers as professionals who plan their crimes and learn from their experiences as they advance through their criminal 'career' (Matthews 2002). In contrast, then, is the perspective that robbery is less rational or planned and more routed in street culture and identity.

While these perspectives seem disparate, both are offered support from the fact that robbery offences are often carried out in groups. While an instrumental perspective on co-offending may lend support to the rational choice model of robbery, theories of group influence may help to explain the more expressive forms of robbery that enhance street status.

\section{Motlvations for group robbery: Instrumental}

Given the complexity involved in targeting large, security-conscions commercial establishments, who often have high numbers of staff as well as customers, it may be unsurprising that a large proportion of commercial robberies involve multiple offenders. For example, studies have demonstrated that one-third of Australian bank robberies (Marsden 1989) and $59 \%$ of Ganadian robberies (Gabor ef al, 1987 ) inrolved two or more co-offenders and almost 80\% of armed bank robbers in the US (Haran and Mastin 1984) conmitted the crime with one or more accomplices.

Brown, Jennifer M. (Editor); Campbell, Elizabeth A. (Editor). Cambridge Handbook of Forensic Psychology.

Cambridge, GBR: Cambridge University Press, 2010. p 564.

http://site .ebrary.com/lib/griffith/Doc?id=10392876\&ppg $=564$

Copyright $\odot$ 2010. Cambridge University Press. All rights reserved.

May not be reproduced in any form without permission from the publisher, except fair uses permitted under U.S. or applicable copyright law. 
For armed robbery (commercial), it has been suggested that co-offending has an instrumental advantage, with the number of offenders allowing role differentiation, therefore providing a division of labour that increases the ease with which the robbery is executed. Einstadter (1969) explains that a basic triad of roles' is necessary for successful robberies and, therefore, most armed robbers operate in groups of three one remins outside near an automobile while two enter the establishment, armed, one as a back-up to watch customers and prevent them from leaving while one gathers the money. According to Einstadter, if the size and complexity of the robbery require, more people mar take part but do not typically perform roles different to the basic triad.

Role differentiation has been identifed in amed robbers through interviews by Mckluskey and Wardle (2000) and also in ram-raiding teams (Donald and Wilson 2000). The latter study also found that offenders' roles within the robbery corresponded to their criminal history. For example, the 'back-up' (or 'heavy' as Donald and Wilson prefer) tended to have previous convictions for violent offences in contrast to 'drivers' who had previous convictions for non-violent offences.

With role differentiation, there can also be differences in status. Mckluskey and Wardle (2000) found evidence of hierarchical structures in the roles of amed robbers, although hierarchical groups were associated with more experienced offenders. However, even in those cuses where offenders claimed not to have a leader, they still detailed that one menber of the group took on the role of 'planner', being consulted for advice, having ideas and helping to organize the group for the offence.

\section{Motlvatlons for group robbery: group Influence}

However, there is evidence that less 'sophisticated" wtreet robberies also often involve multiple offenders with some form of structure. In the UK, Snith (2003) reported that $60 \%$ of personal robberies involve multiple offenders. Porter and Alison (2006b) specifically examined group robbery (both commercial and personal) for the presence of leadership. Leadership was hypothesized to inrolve decision making, order giving and taking action (or being the first to act, without the direct influence of another) throughout the different stages of the offence. Leaders were identified in $98 \%$ of the 105 cises, with decision making common to all but initial action being the most common form of leadership over autocntic order giving, Further, the nost common group structure was a simple dichotomous leader/follower structure, where one group member (leader) displayed influence behaviour to a higher degree

Brown, Jennifer M. (Editor); Campbell, Elizabeth A. (Editor). Cambridge Handbook of Forensic Psychology.

Cambridge, , GBR: Cambridge University Press, 2010. p 565.

http://site,ebrary.com/lib/griffith/Doc?id=10392876\&ppg=565

Copyright $(C) 2010$. Cambridge University Press. All rights reserved.

May not be reproduced in any form without permission from the publisher, except fair uses permitted under U.S. or applicable copyright law. 
than all the other group nembers (followers) and the followers were equal to one another in the amount of influence they displayed. No discernable quantitative or qualitative differences were observed in the leadership of conmertial and personal robbery groups, indicating that both have similar structures and influence processes.

Indeed, Porter and Alison (2016b) indicated that the high incidence of particjpative leadership of group robbers over autocratic leadeship may be due to the age of the offenders. Porter and Alison (2006a) noted that group robbery is typically committed by young males in groups of two or thee upon young males. Gabor at al. (1997) also noted that $85 \%$ of robbery offenders in their sample were under 25 years old with 18 - to 21 -year-olds being the highest-frequency age group for robbers, Further, within their groups, robbery offenders tend to be of a similiar age to one another. Porter and Alison (2006b) suggest that more autocratic forms of leadership may be more likely where groups are organized, older or have more variation in age between members, thus suggesting that leadership style may be dependent on the legitimacy of the leader's position in the group.

Evidence suggests, however, that group robbery is typically committed by male youth peer groups. Indeed, co-offending in general has been found to be more prevalent anong youth than adults (Reiss 1988). For young people, the peer group can become a significant source of reinforcement at a time when they are striving for autonomy from adults and asserting their own identity (Corsaro and Eder 1900). Un fortunately, the desire for stitus and acceptance among peers may encourage antisocial behaviour, particularly through the active leaders outlined above, whereby co-offending is likely to be borne out of group influence rather than any instrumental need for division of labour.

\section{Conclusion}

It is clear that different perspectives on robbery highlight different features of the crime. While some researchers draw a picture of robbery is incorporating sophisticated planuing, division of labour and professionalism, others view robbery as an exanple of status-enhancing behaviour in juvenile peer groups.

Somewhat in response to this, Wright of a. (2006) argue that research into British robbery has tended to focus only on commercial robbery, thus producing a particular focus on tinancial notives, with many reporting robbers to spend their money on subsistence or future investment (for example, Matthews 2002). However, Matthews (2002) and Hobbs (1995) have noted

Brown, Jennifer M. (Editor); Campbell, Elizabeth A. (Editor). Cambridge Handbook of Forensic Psychology. Cambridge, , GBR: Cambridge University Press, 2010. p 566.

http://site.ebrary.com/lib/griffith/Doc?id=10392876\&ppg=566

Copyright (C) 2010. Cambridge University Press. All rights reserved.

May not be reproduced in any form without permission from the publisher, except fair uses permitted under U.S. or applicable copyright law. 
a change from robbery as a professional crime to a more recent frugmentation into different forms of criminality. Barker of al. (1993) and Smith (2003) found that groups of young street robbers were more likely to be motivated by status and reputation and Matthews (2002) notes that even some commercial robbers spend money on frivolous, luxury items.

However, regardless of motive or target, robbery tends to be a group phenomenon, with group processes and pattems evident even in the least skilled or planned crimes. However, whether these group patterns are a product of the crime or the crime a product of the group is still a question for future research. Cause and effect with multivariate real-world phenomena will always have its challenges (and challengers), and future studies will need at the very least to consider how different motives may be mediated by the number, and characteristics, of those involved as well as the behaviour that they display and the turget towirds which it is directed.

\section{FURTHER READING}

Ponter and Mison (2006, b) offer mure detal of the analyses present in this brief werview of types of robbers and also assoniated behaviours.

\section{REFERENCES}

Alisan, L, Rocket, W., Deprez, S, and Watls, S. (2000) Bandit, cowboys and Robin's men: the

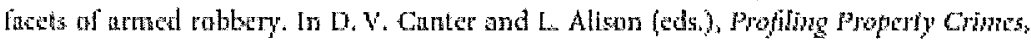
pp. 75-106. Adershot: Ashgale.

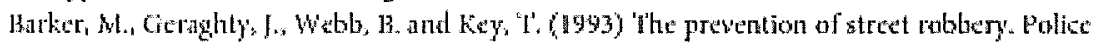
Research Group Crime 'sevention Lnif Series paper no. 4t. London: Hone Ofice Police Dejartinent.

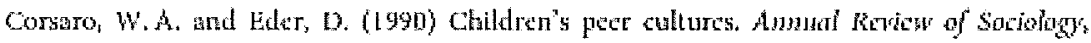
16: $197-220$

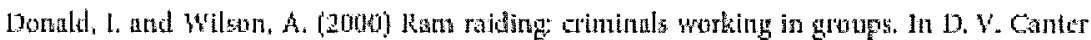

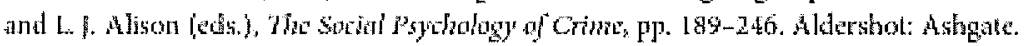

Linstadler, W. J. (1569) the social organisation of armed robtery. Sociat problems, 17: 64-93.

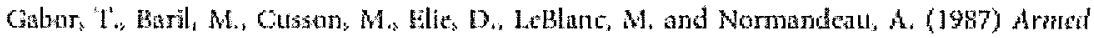

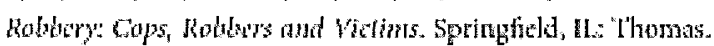

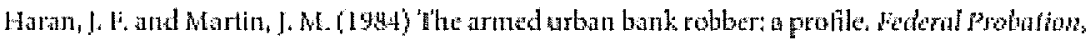
$48: 47-73$

Brown, Jennifer M. (Editor); Campbell, Elizabeth A. (Editor). Cambridge Handbook of Forensic Psychology.

Cambridge, , GBR: Cambridge University Press, 2010. p 567.

http://site.ebrary.com/lib/griffith/Doc?id=10392876\&ppg $=567$

Copyright (C) 2010. Cambridge University Press. All rights reserved.

May not be reproduced in any form without permission from the publisher, except fair uses permitted under U.S. or applicable copyright law. 
Hobbs, D. (1995) Bad Business: Professional Crime in Modern Britain. New York: Oxford Liniversity Presz.

Jacubs, B. A. and Wright, R. (1999) stick-up, street culure and offender motivation. Crimirlology, $37: 149-73$.

Leary, '1. (1957) Inderpersonal Diagnosis af Persomalidy. New York- Konald Press.

Maraden, J. (1989) Bank robbery in Australia. In D. Challinger (ed.), A rmed Robbery, pp. 25-36. Canberra: Austealian Institute of Criminology.

Mathews, R. (20102) Amed Robsery. Cullompton: Willan.

MeCluskey $K$. and Wirdle, 5. (2000) 'l'he secinl struture of robbery, In D. V. Canter and 1. J. Alison (eds.), 'the Soetal Pschology of Crime, pF. 247-85. Aldershot: Ashgate.

Porter, L. E. and Alison, L. J. (2006a) Bebavioural coherence in graup robbery: a circumplex madel of offender and vistim inleraetions. Aggresive Buhrior, 32: 330-42.

(20065) Leadership and hitrarchies in criminal groups: scaling degrets of leading Lehaviour in group robbery. Legul and Criminological Psychology, 11: 245-65.

Reiss, A. J. (1988) Go-ofending and crintinal carecrs. In M. 'l'ongy and N. Morris (eds.), Crinte and fustice: A Review of Reserd, vol. 10. Chicago: Universily of Chicago Press.

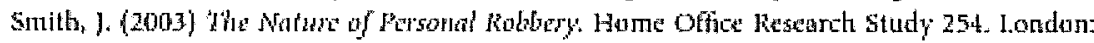
Home office.

Wright, $R$, Brookman, $l$, and Bennett, ' $l$ '. (2006) 'the fortsround dynamics of stret roblery' in Britain. British joumal of Criminolugy 46:1-15

Wright, fhand Decker, S. H. (1997) Armed Robbers in Aclion, Boston, MA: Northeastern Unversity Press.

Brown, Jennifer M. (Editor); Campbell, Elizabeth A. (Editor). Cambridge Handbook of Forensic Psychology.

Cambridge, , GBR: Cambridge University Press, 2010. p 568.

http://site.ebrary.com/lib/griffith/Doc?id=10392876\&ppg=568

Copyright $(C 2010$. Cambridge University Press. All rights reserved.

May not be reproduced in any form without permission from the publisher, except fair uses permitted under U.S. or applicable copyright law. 